\title{
Factors related to stress in divorces with child custody
}

\section{Fatores relacionados ao estresse em divórcios \\ envolvendo guarda da prole}

\author{
Tatiana Torres de VASCONCELOS ${ }^{1}$ \\ Cláudia Moura de MELO $^{2}$ \\ Marlizete Maldonado VARGAS 3 \\ Cleberson Franclin Tavares COSTA ${ }^{3}$
}

\begin{abstract}
This paper presents a study with 78 adults in situations of divorce and child custody in the Public Defender's Office of Sergipe, Brazil in order to verify the occurrence of stress symptoms. The application of the Stress Symptoms Inventory, validated by Lipp, revealed that $71.8 \%$ of the participants experienced stress, and $51.8 \%$ of these were in the resistance phase and $82.1 \%$ predominantly presented psychological symptoms. Stress levels were related to being a woman (Odds Ratio $=6.43$; Confidence Interval $=2.58-21.63 ; p=0.001$ ) and job instability $\left(\chi^{2}=7.972 ; p=0.019\right)$. The age of the oldest child at the time of divorce is also related to stress: the older the child, the less likely the occurrence of stress (Odds Ratio $=0.925$; Confidence Interval $=0.86-0.98 ; p=0.03$ ). The conclusion is the there is a need for family preventive interventions in order to support marital bonds, facilitating relational arrangements required during the time of separation.
\end{abstract}

Keywords: Child custody; Divorce; Stress.

\section{Resumo}

Este trabalho apresenta um estudo realizado com 78 adultos que iniciaram processo de divórcio e guarda da prole na Defensoria Pública de Sergipe com a finalidade de verificar a ocorrência de sintomas de estresse. A partir do Inventário de Sintomas de Stress para Adultos de Lipp obteve-se que 71,8\% dos participantes apresentaram estresse, sendo que $51,8 \%$ estavam na fase de resistência e $82,1 \%$ com sintomas predominantemente psicológicos. Os níveis de estresse mostraram relação com o gênero feminino (Odds Ratio $=6,43$; Intervalo de Confiança $=2,58-21,63 ; p=0,001$ ) assim como a instabilidade no mercado de trabalho $\left(\chi^{2}=7,972 ; p=0,019\right)$. Verificou-se ainda que a idade do filho

\section{$\boldsymbol{\nabla} \mathbf{v} \boldsymbol{v}$}

1 Universidade Tiradentes, Centro de Ciências da Saúde, Curso de Psicologia. Av. Murilo Dantas, 300, 49010-390, Farolândia, Aracaju, SE, Brasil. Correspondência para/Correspondence to: T.T. VASCONCELOS. E-mail: <tati.tv@hotmail.com>.

2 Universidade Tiradentes, Programa de Pós-Graduação em Saúde e Ambiente, Laboratório de Biologia Molecular. Aracaju, SE, Brasil.

${ }^{3}$ Universidade Tiradentes, Programa de Pós-Graduação em Saúde e Ambiente, Laboratório de Planejamento e Promoção da Saúde. Aracaju, SE, Brasil.

Article based on Master's thesis of T.T. VASCONCELOS, intitled: "Stress and coping in divorces with children custody". Universidade Tiradentes, 2014. 
mais velho no momento da separação possui relação com níveis de estresse, pois quanto maior a idade do filho, menor a chance de ocorrência de estresse (Odds Ratio =0,925; Intervalo de Confiança $=0,86-0,98 ; p=0,03$ ). Conclui-se que há necessidade de intervenções familiares preventivas, a fim de cuidar do vínculo conjugal, facilitando os arranjos relacionais requeridos pela separação.

Palavras-chave: Custodia da criança; Divórcio; Estresse.

Changes and challenges faced during a divorce are related to stressful events. This period, however, can be regarded either as a chance for the family to mature and establish more satisfying relationships in the family environment or as a degenerative and threatening process that hinders the development of the family system. In this sense, some people may develop emotional, psychological, or social disorders as a response to the situation (Amâncio, 2008).

Divorces are increasingly a part of social dynamics (Peck \& Manocherian, 2001), enabling new family arrangements. It is not reasonable, however, to naturalize or minimize the complex process of changes related to a divorce, but rather to work out the implications of a situation that is already part of the routine of many families.

A study developed by Brito (2007) addressing children of divorce notes that all attention is needed during this process so that children are not affected by potentially harmful consequences. Among these consequences, we note the difficulty in separating conjugality from parenthood. There are cases in which the separation of the couple is extended to the relationship between parents and children, creating distance between the children and one of the parents.

Determining custody of the children may be a major challenge for the reconfiguration of post-divorce family relationship arrangements. Brazilian studies (Sousa \& Brito, 2011; Wagner \& Grzybowski, 2010) show that, in most cases, women get the custody of children after a divorce.

Social prescriptions of gender may be related to stress symptoms in women when compared to men. One study conducted by Caires and Silva (2011), in the North of Portugal, with students aged from 17 to 20 years old, observed that stress is more frequent among women than in men.
Amâncio (2008) conducted a study with Portuguese families addressing the perception of family stress and verified that a perception of stress is more frequent among women than men. In addition to European studies, stress was also verified among women in Brazilian studies (Lipp, 2000; Wottrich et al., 2011).

In the four-phase stress model proposed by Lipp (2000), stress symptoms are classified into four phases: the first phase is an alertness in which a psychophysiological process begins in response to stressors; the second phase involves resistance, in which the individual is dealing with stressors to maintain internal homeostasis; the third phase is near-exhaustion, in which disease initiates and the more vulnerable organs start showing signs of deterioration; the last phase is exhaustion, at which point physical and/or mental disease has settled in.

Stress involves an internal causal agent (psychological factors) or an external ones (environmental factors); cognitive assessment regarding the situation (harm, threat or challenge); coping strategies (Skinner, Edge, Altman, \& Sherwood, 2003); and a response to stress, which is characterized by psychophysiological changes triggered by different situations, either pleasant or unpleasant (Abreu, Stoll, Ramos, Baumgardt, \& Kristensen, 2002; Justo \& Lipp, 2010).

Stress occurs when cognitive assessment concerning a given situation demands personal resources from an individual beyond those $s / h e$ is able to access to deal with that context. An assessment is the personal meaning (beliefs, values, objectives) one assigns to an event. It influences one's personal (physical, psychological, material or spiritual) resources used to deal with the situation (Carver \& Connor-Smith, 2010; Folkman, 2010). Affective force is expressed in the body in a complex way, motivating actions or behaviors and also physiological changes (Rocha \& Kastrup, 2009). 
Feelings experienced in the times of marital difficulties may be present during the divorce, such as: anger, jealousy, fear, sorrow, frustration, loss, grief, and a sense of depreciation. These affective states are favorable to stress and are related to the way individuals assess or interpret events that are experienced (Lipp, 2013).

Therefore, this study's aim was to verify the occurrence of stress symptoms among individuals interviewed in the Public Defender's Office of Sergipe, Brazil, at the beginning of divorce processes involving issues of child custody and the determinant factors of the meaning of the causal relationship among independent variables (sociodemographic variables, marriage and divorce aspects) and dependent variables (stress symptoms).

\section{Method}

This is a quantitative and qualitative study. An interdisciplinary approach, which links the knowledge of health sciences and human sciences, is used to analyze the phenomenon in order to verify how psychosocial aspects impact the physical, mental and emotional health of people. The survey was conducted in the Public Defender's Office of Sergipe, Brazil in the Central da Cidadania in Aracaju, SE, Brazil from August 2012 to May 2013.

\section{Participants}

A total of 78 adults (49 women and 29 men) composed a convenience sample. These individuals voluntarily consented to participate in the study and signed free and informed consent forms. Because this study is part of a larger project including semistructured interviews, data collection ceased when saturation was reached. Theoretical saturation is achieved when new content, which would enable deeper analysis, is no longer gained (Fontanella et al., 2011).

\section{Instruments}

\section{Stress Symptoms Inventory}

This instrument was validated by Lipp and Guevara in 1994 (Lipp, 2000) and is used to verify the occurrence of stress in adult individuals and the phase it represents (alertness, resistance, nearexhaustion, exhaustion) and whether stress is manifested through a predominant symptomatology (physical and/or psychological). The Stress Symptoms Inventory (SSI) includes 37 items concerning somatic items and 19 psychological items. It's use is indicated for individuals 15 years old or older, adults and elderly individuals.

\section{Semi-structured interview}

This is a qualitative method of investigation (Marconi \& Lakatos, 2011) with focused application. The interview script was composed of closed (objective) and open questions. The questions addressed socio-demographic variables, and aspects concerning marriage and divorce.

\section{Procedures}

One professional and two students from the field of Psychology applied the instruments and stayed at the data collection site for three weeks. A pre-test was initially conducted with $10 \%$ of the sample to make any necessary changes. The interviewer team was trained for the procedure according to the following process: reading the consent form and asking for the participants' signatures. Afterwards, the interviewers completed the SSI (Lipp, 2000) and applied the semi-structured interviews. This process lasted approximately $\mathbf{4 0}$ minutes. Responses were transcribed after each question in order to maintain visual contact and keep attention focused on the interviewee's report. The possibility of recording the reports for later transcription was discarded because the participants were in a special situation in a judicial environment where many of the individuals would not authorize such a procedure.

Socio-demographic data included gender, occupation, profession, income, and education: data regarding marriage included time living together, main difficulties and coping strategies. Data concerning divorce included type of divorce (consensual or litigious), motive, time since separation, 
characterization of the current period, and expectations concerning custody of children.

The study was approved by the Institutional Review Board at the Universidade Tiradentes, Aracaju, SE, Brazil (Process $n^{\circ}$ 110512).

\section{Results}

Simple descriptive analysis (frequency, average, standard deviation) was used to analyze SSI and socio-demographic data. The Chi-square and Fisher's exact test were used for the analysis of bivariate inference and the Mann-Whitney $\mathrm{U}$ test (quantitative) $p<0.05$. Statistical significance was verified between the dependent variable "stress symptoms" and independent variables (sociodemographic variables, marriage and divorce aspects). Univariate logistic regression (simple) was used to verify the non-adjusted Odds Ratio (OR) and multivariate logistic regression (multiple) was used to verify the adjusted OR. Due to the limited number of participants, we used the bootstrap procedure to minimize statistical errors.

The studied population was mainly composed of women ( $n=49,62.8 \%$ ). Ages ranged from 18 to 61 years old, with an average of 34.9 years old (Standard Deviation - SD $=8.47$ ). In regard to the participants' level of education, $25.5 \%$ had not completed middle school, $46.3 \%$ completed high school and $2.6 \%$ had a bachelor's degree.
All the interviewees reported experience in heterosexual affective relationships. Therefore, we opted to consider the analysis from the perspective of gender, since the literature (Amâncio, 2008; Caires \& Silva, 2011; Lipp, 2000) signals that women are more vulnerable to stress symptoms.

Table 1 presents the general results for the occurrence of stress, which was verified in $71.8 \%$ of the individuals. Most (51.8\%) were in the phase of resistance with a predominance of psychological symptomatology (82.1\%).

After the bivariate analyses between the occurrence of stress and the studied variables, we verified that stress is related to gender, age of the oldest child, and to job instability. Table 2 presents the results concerning the factors that simultaneously influence the occurrence of stress, i.e., being female $(\mathrm{OR}=6.99$; Confidence Interval $-\mathrm{Cl}=2.68$ - 22.71; $p=0.001)$ and the age of the oldest child ( $\mathrm{OR}=0.913$; $\mathrm{Cl}=0.82-0.98 ; p=0.02$ ).

\section{Influence of gender and stress}

In regard to the relationship between the participant's gender and the presence or absence of stress, we observed that $75 \%$ of the individuals experiencing stress $(n=56)$ were women $\left(\chi^{2}=12.610\right.$; $p=0.001)$. The intensity of this relationship shows

Table 1

Occurrence of stress during divorce. Public Defender's Office of Sergipe, Aracaju (SE), Brazil, 2014

\begin{tabular}{|c|c|c|c|c|c|c|}
\hline \multirow{2}{*}{ Occurrence of stress } & \multicolumn{2}{|c|}{ Woman } & \multicolumn{2}{|c|}{ Men } & \multicolumn{2}{|c|}{ Total } \\
\hline & $n=49$ & $\%$ & $n=29$ & $\%$ & $n=78$ & $\%$ \\
\hline Yes & 36 & 73.6 & 8 & 26.4 & 56 & 71.8 \\
\hline No & 16 & 33.3 & 19 & 66.7 & 22 & 28.2 \\
\hline \multicolumn{7}{|c|}{ Phase (Four-phase model) } \\
\hline Alertness & 6 & 12.8 & 6 & 21.4 & 8 & 14.4 \\
\hline Resistance & 25 & 51.3 & 15 & 50.0 & 29 & 51.8 \\
\hline Near-exhaustion & 15 & 30.8 & 6 & 21.4 & 16 & 28.6 \\
\hline Exhaustion & 2 & 5.1 & 2 & 7.1 & 3 & 5.4 \\
\hline \multicolumn{7}{|c|}{ Predominance of Symptoms } \\
\hline Physical & 6 & 12.8 & 6 & 21.4 & 8 & 14.3 \\
\hline Psychological & 41 & 84.6 & 23 & 78.6 & 46 & 82.1 \\
\hline Both & 1 & 2.6 & 0 & 0 & 2 & 3.6 \\
\hline
\end{tabular}


that women experiencing a divorce are seven times more likely to experience stress than are men $(\mathrm{OR}=6.43 ; \mathrm{Cl}=2.58-21.63 ; p=0.001)$. In the near-exhaustion phase, women present 10 percentage points greater likelihood of stress than men.

Table 2

Odds Ratio between occurrence of stress and studied variables. Survey conducted in the Public Defender's Office of Sergipe, Aracaju (SE), Brazil, 2014

\begin{tabular}{|c|c|c|c|}
\hline Variables & Non-adjusted Odds Ratio & $p$ - value & Adjusted Odds Ratio \\
\hline \multicolumn{4}{|l|}{ Sex } \\
\hline Male & 1 & & 1 \\
\hline Female & $6.429(2.578 ; 21.631)$ & 0.001 & $6.999(2.685 ; 22.71)$ \\
\hline \multicolumn{4}{|l|}{ Income (MW) } \\
\hline Up to 1 times the MW & 1 & & \\
\hline More than 1 times and up to 2 times the MW & $1.167(0.319 ; 3.802)$ & 0.779 & \\
\hline Up to 3 times the MW & $1.493(0.16 ; 1.21 \mathrm{E} 9)$ & 0.539 & \\
\hline \multicolumn{4}{|l|}{ Age } \\
\hline Up to 25 years old & 1 & & \\
\hline 26 to 33 years old & $1.15(0 ; 2.165)$ & 0.772 & \\
\hline 34 to 41 years old & $0.472(0 ; 1.328)$ & 0.284 & \\
\hline 42 years old or older & $0.333(0 ; 1.196)$ & 0.179 & \\
\hline \multicolumn{4}{|l|}{ Marriage duration } \\
\hline Up to 7 years & 1 & & \\
\hline 8 a 21 years & $1.65(0.464 ; 5.705)$ & 0.363 & \\
\hline More than 22 years & $0.833(0.089 ; 1.01 \mathrm{E} 9)$ & 0.766 & \\
\hline \multicolumn{4}{|l|}{ Family Arrangement } \\
\hline First & 1 & & \\
\hline Second & $0.612(0.038 ; 8.08 \mathrm{E} 8)$ & 0.489 & \\
\hline Third & $0.735(0 ; 8.8 \mathrm{E} 8)$ & 0.454 & \\
\hline Age (oldest child) & $0.925(0.859 ; 0.984)$ & 0.026 & $0.913(0.825 ; 0.982)$ \\
\hline Stepchildren & $0.522(0.111 ; 1.432)$ & 0.296 & \\
\hline \multicolumn{4}{|l|}{ Time since separation } \\
\hline 0 (live together) to 1 year & 1 & & \\
\hline 2 to 6 years & $0.409(0.035 ; 5.1 \mathrm{E} 8)$ & 0.188 & \\
\hline More than 7 yeas & $1.021(0 ; 8.5 \mathrm{E} 7)$ & 0.614 & \\
\hline \multicolumn{4}{|l|}{ Type of divorce } \\
\hline Consensual & 1 & & \\
\hline Litigious & $0.783(0.244 ; 3.007)$ & 0.645 & \\
\hline Stable union & $5.9 \mathrm{E} 9(2.8 \mathrm{E} 8 ; 1.04 \mathrm{E} 9)$ & 1 & \\
\hline \multicolumn{4}{|l|}{ Current communication } \\
\hline Difficult (arguments) & 1 & & \\
\hline Through others, non-existent & $0(0 ; 0)$ & 0.999 & \\
\hline Only the necessary concerning the children & $0(0 ; 0)$ & 0.999 & \\
\hline \multicolumn{4}{|l|}{ Housing situation } \\
\hline Friends, relatives, courtesy & 1 & & \\
\hline Rent & $0.625(0.177 ; 1.880)$ & 0.509 & \\
\hline Own & $0.813(0.261 ; 2.007)$ & 0.736 & \\
\hline \multicolumn{4}{|l|}{ Occupational situation } \\
\hline Unemployed & 1 & & \\
\hline Unstable & $5.308(0.568 ; 1.4 \mathrm{E} 9)$ & 0.060 & \\
\hline Stable & $0.659(0.190 ; 1.912)$ & 0.491 & \\
\hline
\end{tabular}

Note: MW: Minimum Wage. 


\section{Influence of the oldest child's age and stress}

To analyze the relationship between children's ages and stress, we considered the "age of the oldest child" because this determines the beginning of the life cycle as a family (Cerveny \& Berthoud, 2002). A total of $53.6 \%(n=30)$ of those experiencing stress had an oldest child between zero and seven years old. Among those experiencing stress and with children within this age range, 40\% $(n=12)$ were in the resistance phase and $40 \%$ $(n=12)$ were in the near-exhaustion phase; $80 \%$ presented predominantly psychological symptoms. The older the oldest child was, the less likely was the occurrence of stress $(\mathrm{OR}=0.925 ; \mathrm{Cl}=0.86-0.98$; $p=0.03)$ (Table 2).

\section{Influence of the individual's situation in the job market and stress}

A total of $43.6 \%$ of the individuals under study reported stable occupations (formally employed or public employee), 32.1\% reported unstable jobs (temporary contracts or freelancer workers) and $24.4 \%$ were unemployed. In this population, one's situation in the job market is related to the occurrence of stress $\left(\chi^{2}=7.972\right.$; $p=0.019)$. Among those who were unemployed, $68.4 \%(n=13)$ experienced stress and, among these, $69.2 \%$ were in the resistance phase. Among those in unstable jobs, $92.0 \%(n=23)$ presented stress: $34.8 \%$ were in the resistance phase and $47.8 \%$ were in the near-exhaustion phase. Among those with stable jobs, $58.8 \%(n=20)$ presented stress and $60.0 \%$ of these were in the resistance phase.

\section{Influence of other factors and stress}

To analyze the age factor in relation to the occurrence of stress, we opted to use the intervals proposed by Zordan, Wagner, and Mosmann (2012): 18 to 24 years old (final adolescence), 25 to 40 years old (young adults), 41 to 60 years old (middle verified that among those experiencing stress, $67.9 \%(n=38)$ were between 25 and 40 years old, that is, were young adults. A significant aspect of this is that all those individuals in the final stages of adolescence $(100.0 \%, \mathrm{n}=7$ ) experienced stress symptoms.

The duration of marriage factor was also verified to check whether there was a relationship between duration of marriage and the occurrence of stress. The average duration of marriage was 10.91 years $(S D=6.744)$, with a minimum of one year and maximum of 30 years; most (55.1\%) individuals reported between 8 and 21 years of marriage. We opted to group families according to the stages of the family life cycle: zero to seven years (formation of the couple and children's births); 8 to 21 years old (raising the children); and from 22 years on (children leave home) (Carter \& McGoldrick, 2001; Zordan et al., 2012). Considering these intervals, we verified that $58.9 \%(n=33)$ of the individuals experiencing stress were in the raising the children stage (8 to 21 years of marriage).

In regard to time since separation, $80.8 \%$ $(n=63)$ reported less than one year. Among those experiencing stress, $71.4 \%$ still lived in the same house or were separated for less than one year (32.1 and $39.3 \%$, respectively). Among those living in the same house, $37.9 \%$ were in the resistance phase and $37.5 \%$ were in the near-exhaustion phase. Resistance in the four-phase model of stress (Lipp, 2000) corresponds to the second phase, in which the individual has to deal with stressors in order to maintain internal homeostasis. If, however, stressors persist, the individual enters the near-exhaustion phase, and physical and/or psychological disease initiates at that point.

Living in the same house and with a short amount of time since separation may indicate that the individual remains exposed to stressors such as marriage difficulties, among which the most frequently mentioned were: betrayal (25.6\%), financial hardships (21.8\%), emotional distance $(19.2 \%)$, and the use of alcohol or other drugs $(16.7 \%)$.

In regard to quality of communication, $57.7 \%(n=45)$ reported that communication no 
longer existed; $26.9 \%(n=21)$ reported that friendly talk existed, but only in regard to what was necessary concerning the children; and $15.4 \%$ ( $n=12$ ) reported communication was difficult (with fights and arguments). The relationship between communication and stress shows that among those experiencing stress symptoms $(n=30), 53.6 \%$ did not communicate at all with their partner or communicated only through intermediaries. Communication among ex-spouses is essential to establishing new relational arrangements, especially to negotiate and define aspects concerning parenthood and the custody of children.

Information related to guardianship was obtained through the semi-structured interviews in which interviewees were asked about their expectations regarding the custody of their children. Content analysis was used to analyze the reports concerning expectations regarding guardianship (Bardin, 2011). The reports were transformed into five units of context related to the category of guardianship: unilateral maternal custody; unilateral paternal custody; grandparents' custody; joint custody; and split children.

The results indicate that $67.9 \%(n=53)$ of the individuals expected unilateral maternal custody; only one individual expected unilateral paternal custody. The reports revealed a concern on the part of the women regarding the ability of their ex-spouses to take care of their children, fear of losing their caregiver role, or losing the love of their children, as the following excerpts shows:

... . I don't want to leave my children with him because he drinks, brings women home. I don't want my children to see what their father does, I am concerned (Maria, 22 years old, woman).

.... She says that only when he (son) grows up... . I went to see him yesterday, but she won't allow him spend the weekend with me because we're going to another woman's house. I see him occasionally (Luís, 42 years old, men).

In another interview, Marina (34 years old, woman) says her daughter does not want to see the father. She reported that she wanted joint custody but her ex-spouse uses the child to get closer to her. Rosa (29 years old, woman), in turn, states that the father does not visit their 4-year old daughter and reported that her aunt, who took care of them after separation, says she would not allow the father to leave the house with the child. A question arises: does the father have parental difficulties or is his bond with the daughter impeded by the extended family (mother's aunt, with whom the child lives)? Or does the problem consist of both?

\section{Discussion}

The study was conducted with individuals who came to the Public Defender's Office of Sergipe, Brazil, where the divorce process is initiated. Therefore, the fact that the sample is mainly composed of women shows that the initiative to ask for a divorce predominantly comes from the women. This fact was also observed in studies conducted by Féres-Carneiro (2003) and Zordan et al. (2012), who showed that in most instances, the desire and the decision to divorce comes from women.

According to Féres-Carneiro (2003), men more easily remain in a failing romantic relationship because they separate sex from affective relationships. The male conception of marriage holds the constitution of a family to be a more significant factor than is a loving relationship.

Stress was mainly verified among women, a tendency also observed by Lipp (2000) in the SSI validation studies conducted in many regions of Brazil. Similar results were observed in the Portuguese population in a study conducted in Portugal by Amâncio (2008) with reconstituted families in the post-divorce phase. Women presented a higher level of family-stress perception.

The presence of stress in most women from the studied population may be related to psychosocial aspects related to gender, such as the socio-cultural belief that women are more prepared to take care of others (spouses, children and elderly individuals) and be responsible for maintaining family relationships (Carter \& McGoldrick, 2001). 
Therefore, social prescriptions of gender legitimate the guardianship of children as the primary function of women and challenge exspouses to negotiate satisfactory relational arrangements in order to maintain parenthood after conjugality is dissolved. There are significant differences related to gender issues showing that the life cycle of women (Peck \& Manocherian, 2001) has characteristics that are favorable to the development of stress when facing a divorce. Sociocultural issues lead mothers to distrust fathers' abilities to take care of children and some men also believe they do not fit the caregiver role.

Insecurity of a woman concerning the ability of her ex-spouse to take care of children is also associated with other reasons, such as jealousy and the fear of losing children's love and their role as caregiver. We verified that being distant from one of the parents, usually the father, in addition to socio-cultural aspects, may also be related to parental difficulties, as stated by Bolaños (2002), considering the possibility that one of the parents has difficulties performing the relevant role of mother or father.

Sousa and Brito (2011) consider the instability experienced during the period of a divorce to favor the establishment of bonds with the parent who has custody of the children and this strengthening may lead children to experience insecurity and a conflict of loyalty, depending on how the ex-spouses relate with each other. In some cases, fears for children living with the father are justified due to dysfunctional behavior, such as violence or the abusive use of alcohol or other drugs.

In this context of conflicts and distrust, maintaining satisfactory communication that at least enables the negotiation of aspects related to the upbringing of children seems to be a great challenge. Most of the interviewed individuals reported being unable to directly communicate with their ex-partner.

On the other hand, communication with ex-spouses is less important as children become more independent and more able to directly communicate with each of the parents. This survey revealed that the older the child, the less likely is the occurrence of stress. The fact that the child is more independent may decrease concerns regarding who will take care of his/her needs and the child her/himself has greater autonomy to communicate with both parents and become responsible for negotiating and expressing his/her needs.

Other studies (Brito, 2007; Sousa, 2010; Wagner \& Grzybowsky, 2010) addressing divorce suggest that it is necessary to create support services to assist post-divorce families in order to facilitate communication between ex-spouses regarding children, facilitating relational arrangements. The priority of this facilitation is the children's well-being in the face of the complex process of changes that characterize a divorce.

Thus, stress among most women in a situation of divorce seems to be related to the fact that, in most instances, they have the responsibility to provide emotional support and daily care at the same time as they are restructuring their affective, social and economic lives. Additionally, there is the challenge of establishing new relational arrangements, especially in regard to the custody of children and to communication with the ex-spouse, which is necessary to deal with issues concerning the children.

In addition to gender and the age of the oldest child, we also verified that an unstable occupational situation is a factor that leaves people more vulnerable to stress during the process of a divorce. Being a freelance worker or having temporary work contracts impedes individuals from making financial plans in the medium and long terms. This fact, coupled with the process of separation, in which the budget of two people becomes a one-person budget, indicates a potentially stressful situation for the studied population.

Another issue verified here was that the shorter the time since separation, the higher the occurrence of stress. Living in the same house and being separated for a short period of time are factors that maintain or aggravate stress, because the individuals continue to be exposed to stressors in the relational dynamics of their marriage (e.g., infidelity, use of drugs, arguments). Lipp (2013) 
states that in cases in which partners of a marital relationship face difficult situations like marital infidelity, in which trust is lost and there is difficulty in reaching forgiveness, stress in one or both partners may reach high levels for prolonged periods, possibly triggering associated diseases.

This study was conducted in the environment of a public defender's office and the situation of seeking legal support concerning divorce issues may be stressful by itself. Legal guidance available is restricted to legal aspects that do not concern making adjustments, such as learning to live with joint custody.

The aspects studied here are part of a complex relational web, outlining the systemic and multi-determined nature of the events experienced in the affective context in which the individuals involved in a divorce make choices and relational arrangements.

The fact that most of the individuals present a symptomatology that is predominantly psychological and then also experience resistance to stress shows that they are seeking internal homeostasis, or psychophysiological balance. In this phase, psychological symptoms described in SSI (Lipp, 2000) include: increased motivation, sudden enthusiasm, and a sudden urge to initiate new projects, as presented in Table 1.

This study also shows how important the presence of specialized help is to negotiating relational arrangements. Successful and new relational arrangements are not possible without healthy communication between ex-spouses. Family mediation (Cezar-Ferreira, 2011) has been used when conflict has become entrenched.

This study's results reveal the need to provide families with support services and specialized guidance in the post-divorce period. The results also show that there is a lack of preventive measures, such as marital education programs, to prevent more serious relational problems that harm the mental and somatic health of those involved and that impede the healthy exercise of parenthood, essential for the development of children, according to the observations of Wagner and Mosmann (2011).

\section{Contributors}

All authors contributed to conception, design, analysis and interpretation of data, review and final approval of the article.

\section{References}

Abreu, K. L., Stoll, I., Ramos, L. S., Baumgardt, R. A., \& Kristensen, C. H. (2002). Estresse ocupacional e síndrome de Burnout no exercício profissional da Psicologia. Psicologia: Ciência e Profissão, 22(2), 2229. Recuperado em setembro 29, 2013, de http:// pepsic. bvsalud. org /scielo. .php? pid=S1414-98932002 000200004\&script=sci_arttext\&tIng=e

Amâncio, A. V. C. (2008). Stress familiar, estratégias de coping e percepção da qualidade de vida em familias pós-divórcio e familias reconstruídas (Dissertação de mestrado não-publicada). Universidade de Coimbra, Portugal.

Bardin, L. (2011). Análise de conteúdo. São Paulo: Edições 70.

Bolaños, I. (2002). El síndrome de alienación parental. Descripción y abordajes psico-legales. Psicopatología Clínica, Legal y Forense, 2(3), 25-45.

Brito, L. M. T. (2007). Família pós-divórcio: a visão dos filhos. Psicologia: Ciência e Profissão, 27(1), 32-45.

Caires, S., \& Silva, C. (2011). Fatores de stress e estratégias de coping entre adolescentes no $12^{\circ}$ ano de escolaridade. Estudos de Psicologia (Campinas), 28(3), 295-306. http://dx.doi.org/10.1590/\$0103-166X201 1000300001

Carter, B., \& McGoldrick, M. (2001). As mudanças no ciclo de vida familiar: uma estrutura para a terapia familiar. Porto Alegre: Artmed.

Carver, C. S., \& Connor-Smith, J. K. (2010). Personality and coping. Annual Review of Psychology, 61, 679-704.

Cerveny, C. M., \& Berthoud, C. M. E. (2002). Visitando a família ao longo do ciclo vital. São Paulo: Casa do Psicólogo.

Cezar-Ferreira, V. A. M. (2011). Mediação familiar. In L. C. Osório \& M. E. P. Valle. (2011). Manual de terapia familiar II. Porto Alegre: Artmed.

Féres-Carneiro, T. (2003). Separação: o doloroso processo de dissolução da conjugalidade. Estudos de Psicologia (Natal), 8(3), 367-374. http://dx.doi.org/10.1590/S 1413-294X2003000300003

Folkman, S. (2010). Stress, coping and hope. PsychoOncology, 19(9), 901-908. http://dx.doi.org/10.1002/ pon.1836

Fontanella, B. J. B., Luchesi, B. M., Saidel, M. G. B., Ricas, J., Turato, E. R., \& Melo, D. G. (2011). Amostragem 
em pesquisas qualitativas: proposta de procedimentos para constatar saturação teórica. Cadernos Saúde Pública, 27(2), 389-394. Recuperado em junho 6, 2013, de http://www.scielosp.org/pdf/csp/v27n2/20.pdf

Justo, A. P., \& Lipp, M. E. N. (2010). A influência do estilo parental no stress do adolescente. Boletim Academia Paulista de Psicologia, 30(79), 363-378. Recuperado em setembro 24, 2013, de http://www.redalyc.org/ articulo.oa? $\mathrm{id}=94615412010$

Lipp, M. E. N. (2000). Manual do inventário de sintomas de stress para adultos de Lipp (ISSL). São Paulo: Casa do Psicólogo.

Lipp, M. E. N. (2013). O stress está dentro de você. São Paulo: Contexto.

Marconi, M. A., \& Lakatos, E. M. (2011). Técnicas de pesquisa: planejamento e execução de pesquisas, amostragens e técnicas de pesquisa, elaboração, análise e interpretação de dados. São Paulo: Atlas.

Peck, J. S., \& Manocherian, J. (2001). O divórcio nas mudanças do ciclo de vida familiar. In B. Carter \& M. Mcgoldrick. As mudanças no ciclo de vida familiar: uma estrutura para terapia familiar ( $2^{a}$ ed.). Porto Alegre: Artes Médicas.

Rocha, J. M., \& Kastrup, V. (2009). Cognição e emoção na dinâmica da dobra afetiva. Psicologia em Estudo, 14(2), 385-394. http://dx.doi.org/10.1590/S1413-737 22009000200020

Skinner, E. A., Edge, K., Altman, J., \& Sherwood, H. (2003). Searching for the structure of coping: A review and critique of category systems for classifying ways of coping. Psychological Bulletin, 129(2), 216-269. http://dx.doi.org/10.1037/0033-2909.129.2.216

Sousa, A. M. (2010). Síndrome de alienação parental: novo tema nos juízos de família. São Paulo: Cortez.

Sousa, A. M., \& Brito, L. M. T. (2011). Síndrome da alienação parental: da teoria norte-americana à nova lei brasileira. Psicologia: Ciência e Profissão, 31(2), 268-283. http://dx.doi.org/10.1590/S1414-9893201100 0200006

Wagner, A., \& Grzybowski, L. S. (2010). O envolvimento parental após a separação/divórcio. Psicologia: Reflexão e Crítica, 23(2), 189-198. http://dx.doi.org/ 10.1590/S0102-79722010000200011

Wagner, A., \& Mosmann, C. P. (2011). Educar para a conjugalidade: que a vida não nos separe. In L. C. Osório \& M. E. P. Valle. Manual de terapia familiar II. Porto Alegre: Artmed.

Wottrich, S. H., Ávila, C., Machado, C. C., Goldmeier, S., Dillenburg, D., Kuhl, C. P., ... Ruschel, P. P. (2011). Gênero e manifestação de stress em hipertensos. Estudos de Psicologia (Campinas), 28(1), 27-34. http:// dx.doi.org/10.1590/S0103-166X2011000100003

Zordan, E. P., Wagner, A., \& Mosmann, C. (2012). O perfil de casais que vivenciam divórcios consensuais e litigiosos: uma análise das demandas judiciais. PsicoUSF, 17(2), 185-194. http://dx.doi.org/10.1590/ S1413-82712012000200002

Received: February 12, 2014

Final version: July 29, 2014

Approved: October 10, 2014 